\title{
Periphyton composition and diversity in the Kaunas Lagoon and the Nemunas River ${ }^{1}$
}

\author{
Rasa Glasaitè, \\ Ingrida Šatkauskien $\dot{e}^{\star}$ \\ Department of Biology, \\ Vytautas Magnus University, \\ Vileikos 8, \\ LT-44404 Kaunas, \\ Lithuania
}

\begin{abstract}
Periphyton is a biological layer found in various substrata in natural waters and consists of bacteria, algae, fungi, protozoa, and small metazoans. It plays an important role in trophic and functional dynamics in freshwater ecosystems.

The Kaunas Lagoon and the Nemunas River are among important freshwater ecosystems in Lithuania. However, little is known about periphytic communities in these freshwater habitats. The aim of this investigation was to determine the taxonomic composition and diversity of periphytic organisms in the Kaunas Lagoon and the Nemunas River.

Periphyton samples were collected from the stones at regular intervals to compare periphytonic community structure and to examine its temporal changes. Totally, 28 taxa of periphyton were collected and identified. Most of the taxa belonged to Bacillariophyta. In all locations the dominant species were diatoms Navicula lanceolata, Craticula cuspidata, Amphora ovale. Seasonal assessment of the distribution of periphyton shows that in both water bodies more organisms were found in late summer. The seasonal succession of the periphyton community was more significant in the Nemunas River.
\end{abstract}

Key words: periphyton, algae, freshwater, Lithuania

\section{INTRODUCTION}

Periphyton is a biological layer found in various substrata in natural waters and consists of bacte-

\footnotetext{
* Corresponding author. E-mail: i.satkauskiene@gmf.vdu.lt
}

ria, algae, fungi, protozoa, and small metazoans (Hameed, 2003). It plays an important role in trophic and functional dynamics in freshwater

1 Presentation was made at the 7th International Conference “The Vital Nature Sign” on 16-19 May, 2013. 
ecosystems. Periphytonic organisms in freshwater habitats integrate into benthic food webs as prey for larger animals and/or as consumers of bacteria and algae (Schmid-Araya, Schmid, 2000; Schmid, Schmid-Araya, 2006). In our opinion the research of the periphyton in freshwater habitats of Lithuania is still far too limited. Traditionally most hydrobiological studies have focused on phytoplankton (Kasperovičienè, 2001; Hällfors, 2004; Kalytytè, 2007) and less attention is paid to the attached communities regardless of their growth in the most productive littoral zone of aquatic ecosystems (Wetzel, 2001; O’Reilly, 2006). The Kaunas Lagoon and the Nemunas River are among important freshwater ecosystems in Lithuania that differ by hydrobiological characteristic. However, little is known about periphytic communities in these freshwater habitats. The aim of this investigation was to determine the taxonomic composition and diversity of periphytic organisms in the Kaunas Lagoon and the Nemunas River.

\section{MATERIALS AND METHODS}

Periphyton sampling locations and its characteristics

Periphyton was investigated in stagnant and flowing freshwater systems: the Kaunas Lagoon and the Nemunas River. Samples were collected at six locations: three locations in the Kaunas Lagoon and three locations in the Nemunas River.

The Kaunas Lagoon $\left(54^{\circ} 51^{\prime} 10^{\prime} \mathrm{N}, 24^{\circ} 10^{\prime} 2^{\prime} \mathrm{E}\right.$ $\left.54.852778^{\circ}, 24.167222^{\circ}\right)$ is the largest artificial water body in Lithuania created in 1959 when the Nemunas River was dammed. An average lagoon depth is about $9-12 \mathrm{~m}$, but in deepest locations can reach $22 \mathrm{~m}$. Water level of the Kaunas Lagoon is about $44 \mathrm{~m}$ above sea level. The coast shallow near moraine banks are pebbled and the shallow can become silty in the sandy coast. Shores of the lagoon are dominated by mixed and deciduous forests. Periphyton samples were collected at three locations, the

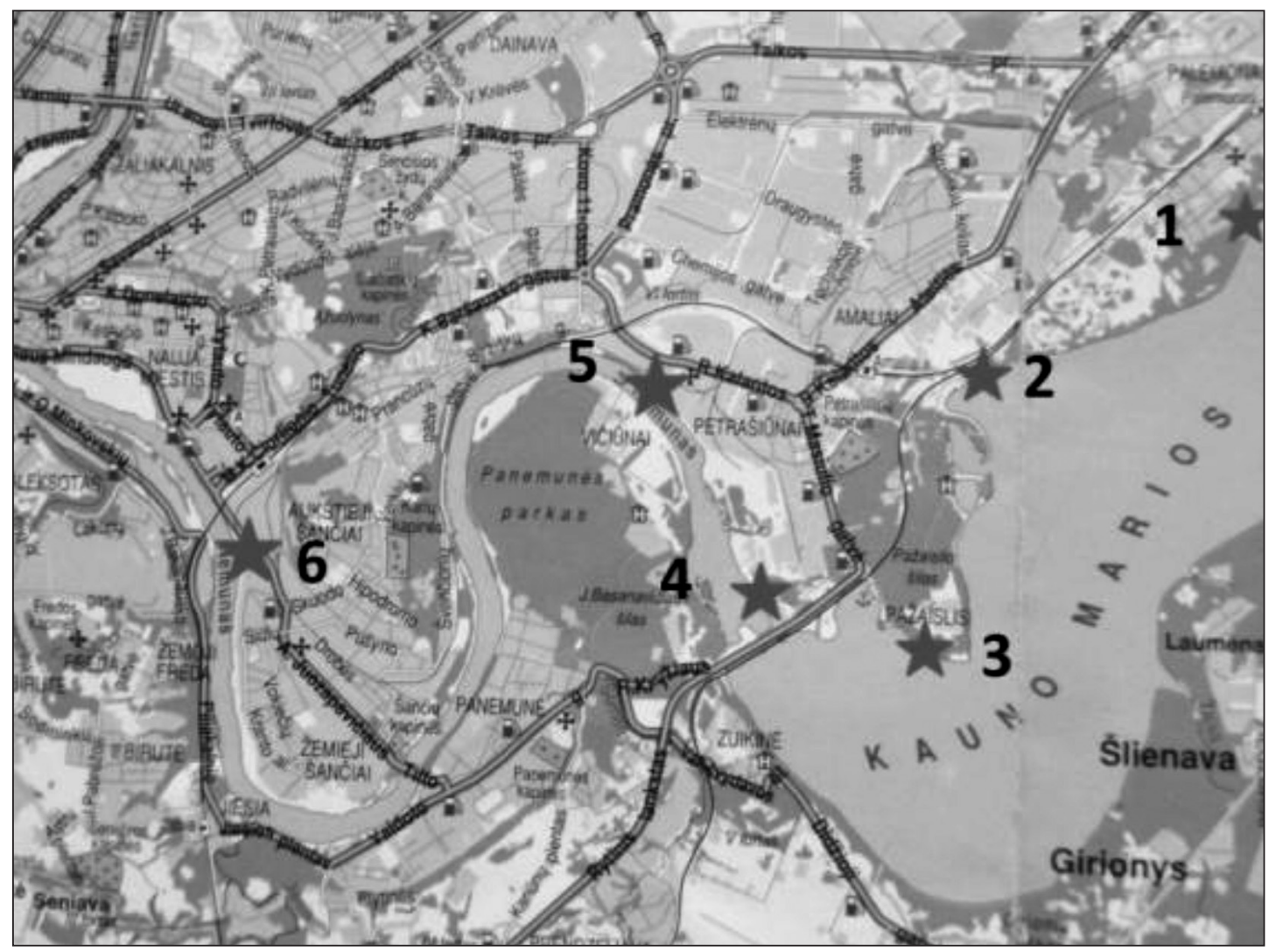

Fig. 1. Periphyton sampling locations in the Kaunas Lagoon and the Nemunas River 
Table 1. Periphyton sampling time, $\mathrm{pH}$ and temperature

\begin{tabular}{|c|c|c|c|c|c|c|c|c|}
\hline \multirow{2}{*}{$\begin{array}{l}\text { Sampling } \\
\text { locations }\end{array}$} & \multicolumn{4}{|c|}{$\mathrm{pH}$} & \multicolumn{4}{|c|}{ Temperature } \\
\hline & June & July & August & $\begin{array}{c}\text { Sep- } \\
\text { tember }\end{array}$ & June & July & August & $\begin{array}{c}\text { Sep- } \\
\text { tember }\end{array}$ \\
\hline 1(lagoon) & 8.1 & 8.4 & 8 & 7.8 & 19 & 24 & 18 & 16 \\
\hline 2(lagoon) & 8.2 & 8.2 & 7.8 & 7.9 & 20 & 23 & 20 & 16 \\
\hline 3(lagoon) & 8.3 & 8.1 & 7.9 & 7.8 & 16 & 23 & 19 & 17 \\
\hline 4(river) & 7.8 & 7.6 & 7.6 & 7.6 & 19 & 21 & 20 & 16 \\
\hline 5(river) & 7.7 & 7.4 & 7.4 & 7.5 & 19 & 20 & 21 & 16 \\
\hline 6 (river) & 7.5 & 7.7 & 7.4 & 7.5 & 18 & 21 & 19 & 16 \\
\hline
\end{tabular}

distance between locations was about $3 \mathrm{~km}$ (Fig. 1).

The Nemunas River $\left(55^{\circ} 04^{\prime} 00, \quad 13^{\prime} \mathrm{N}\right.$ $22^{\circ} 35^{\prime} 50,92^{\prime} \mathrm{E}-53^{\circ} 58^{\prime} 29,43^{\prime} \mathrm{N} 23^{\circ} 54^{\prime} 46,18^{\prime} \mathrm{E}$ ) is the largest river in Lithuania, its length is $937 \mathrm{~km}$ and depth - from 1.5 to $5 \mathrm{~m}$. Periphyton samples were collected at three locations, the distance between locations was about $4 \mathrm{~km}$ (Fig. 1).

Accurate periphyton sampling time, water temperature and $\mathrm{pH}$ are shown in Table 1 .

Periphyton was collected with scalpel from natural substrates - stones, in $40 \mathrm{~cm}$ depth of littoral zone. Samples were transported to laboratory for analysis in 2 hour period after they had been collected. Identification of specimens was based on the keys of Mažeikaite (2003); Patterson (2003); Kelly et al. (2005). Taxonomic nomenclature was adopted according to the most recent checklists (Mather et al., 2010; Andrejić et al., 2012; Baykal Özer et al., 2012).

Relative abundance of species $\left(\mathrm{p}_{\mathrm{i}}\right)$ was calculated by:

$$
\mathrm{p}_{\mathrm{i}}=\mathrm{n}_{\mathrm{i}} / \mathrm{N} \times 100 \%
$$

where $n_{i}$ is a number of individuals of a periphyton species found in the studied sample, $\mathrm{N}$ is the total number of individuals of all periphyton species found in the sample. Species that had $\mathrm{p}_{\mathrm{i}}>5 \%$ were considered as dominant (Durska, 2001). In order to analyze periphyton organisms diversity, species richness ( $S$ ) and Shannon-Wiener's $(\mathrm{H})$ diversity indices were calculated for each site.

\section{RESULTS}

Twenty nine periphyton taxa were found in the Kaunas Lagoon and the Nemunas River. Due to the lack of clear morphological criteria many of the found individuals were identified to genus. Based on the results, 12 species and 12 genera of periphyton in a stagnant water body, the Kaunas Lagoon, were collected (Table 2). Twelve species and 11 genera were collected and identified in flowing water body, the Nemunas River (Table 3). A list of all taxa found, together with their relative abundance per sample is given in Table 2 and Table 3.

\section{DISCUSSION}

After the analysis of the data, we established the same dominant diatoms in comparable proportions during the study period in the Kaunas Lagoon and the Nemunas River: Navicula lanceolata (Bacillariophyta), Craticula cuspidata (Bacillariophyta) and Amphora ovale (Bacillariophyta) (Figs. 2 and 3). The diversity of periphyton organisms in the Kaunas Lagoon $(\mathrm{H}=1.79)$ was slightly higher than in the Nemunas River $(H=1.77)$. Both values are about 1.7 and it means that the species are rather evenly distributed. However, there are some species that are found with only few organisms or very high numbers.

During the investigation period a seasonal change of periphyton organisms was observed.

In June the Kaunas Lagoon was dominated by Amoebae sp. and diatoms: Navicula lanceolata, Craticula cuspidata, Amphora ovale. After a 
Table 2. Periphyton composition and relative abundance in the Kaunas Lagoon $\left(\mathrm{p}_{\mathrm{i}}-\right.$ relative abundance of species, $\mathrm{n}_{\mathrm{i}}-\mathrm{a}$ number of individuals of a periphyton species found in the studied sample)

\begin{tabular}{|c|c|c|c|c|c|c|}
\hline \multirow[t]{2}{*}{ Genus / species } & \multicolumn{2}{|c|}{$\begin{array}{c}1 \text { st } \\
\text { location }\end{array}$} & \multicolumn{2}{|c|}{$\begin{array}{c}\text { 2nd } \\
\text { location }\end{array}$} & \multicolumn{2}{|c|}{$\begin{array}{c}\text { 3rd } \\
\text { location }\end{array}$} \\
\hline & $\mathrm{n}_{\mathrm{i}}$ & $p_{i}$ & $\mathrm{n}_{\mathrm{i}}$ & $p_{i}$ & $\mathrm{n}_{\mathrm{i}}$ & $\mathrm{p}_{\mathrm{i}}$ \\
\hline \multicolumn{7}{|l|}{ Chlorophyta } \\
\hline Cosmarium sp. & 123 & 3.2 & 3 & 0.08 & 3 & 0.07 \\
\hline $\begin{array}{c}\text { Cosmarium } \\
\text { subprotumidum }\end{array}$ & 3 & 0.08 & - & - & - & - \\
\hline $\begin{array}{c}\text { Pediastrum } \\
\text { boryanum }\end{array}$ & 1 & 0.03 & 13 & 0.35 & & \\
\hline $\begin{array}{l}\text { Scenedesmus } \\
\text { communis }\end{array}$ & 178 & 4.62 & 181 & 4.92 & 23 & 0.56 \\
\hline $\begin{array}{c}\text { Actinastrum } \\
\text { aciculare }\end{array}$ & 2 & 0.05 & - & - & 1 & 0.02 \\
\hline \multicolumn{7}{|l|}{ Bacillariophyta } \\
\hline Amphora ovale & 636 & 16.52 & 190 & 5.16 & 422 & 10.22 \\
\hline Cocconeis sp. & 55 & 1.43 & 71 & 1.93 & 161 & 3.9 \\
\hline Craticula cuspidata & 1170 & 30.4 & 1691 & 45.95 & 972 & 23.53 \\
\hline Cymbella aspera & 5 & 0.13 & - & - & 2 & 0.05 \\
\hline Navicula lanceolata & 1187 & 30.84 & 670 & 18.21 & 1936 & 46.87 \\
\hline Pinnularia viridis & - & - & 99 & 2.69 & - & - \\
\hline $\begin{array}{c}\text { Pinnularia } \\
\text { acrosphaeria }\end{array}$ & 73 & 1.9 & 15 & 0.41 & 16 & 0.39 \\
\hline Biddulphia sp. & 1 & 0.03 & - & - & - & - \\
\hline $\begin{array}{c}\text { Cymatopleura } \\
\text { solea }\end{array}$ & 1 & 0.03 & - & - & - & - \\
\hline Didymosphenia sp. & 11 & 0.29 & - & - & - & - \\
\hline $\begin{array}{c}\text { Rhoicosphenia } \\
\text { abbreviata }\end{array}$ & 276 & 7.17 & 538 & 14.62 & 395 & 9.56 \\
\hline Synedra sp. & 45 & 1.17 & 48 & 1.3 & 11 & 0.27 \\
\hline Flagillaria sp. & - & - & 3 & 0.08 & - & - \\
\hline Gomphonema sp. & - & - & 2 & 0.05 & - & - \\
\hline \multicolumn{7}{|l|}{ Ciliophora } \\
\hline Paramecium sp. & 6 & 0.16 & 4 & 0.11 & 53 & 1.28 \\
\hline Vorticella sp. & 8 & 0.21 & 5 & 0.14 & 1 & 0.02 \\
\hline \multicolumn{7}{|l|}{ Rhizopoda } \\
\hline Amoeba sp. & - & - & 38 & 1.03 & - & - \\
\hline \multicolumn{7}{|l|}{ Euglenophyta } \\
\hline Euglena sp. & 65 & 1.69 & 107 & 2.91 & 132 & 3.2 \\
\hline \multicolumn{7}{|l|}{ Rotifera } \\
\hline Rotifera & 3 & 0.08 & 2 & 0.05 & 3 & 0.07 \\
\hline $\begin{array}{l}\text { Total number } \\
\text { of organisms }\end{array}$ & 3849 & 100 & 3680 & 100 & 4131 & 100 \\
\hline $\begin{array}{c}\mathrm{H} \\
\text { (Shannon index) }\end{array}$ & \multicolumn{2}{|c|}{1.79} & \multicolumn{2}{|c|}{1.71} & \multicolumn{2}{|c|}{1.53} \\
\hline $\begin{array}{c}\text { S } \\
\text { (species richness) }\end{array}$ & \multicolumn{2}{|c|}{20} & \multicolumn{2}{|c|}{18} & \multicolumn{2}{|c|}{15} \\
\hline
\end{tabular}


Table 3. Periphyton composition and relative abundance in the Nemunas River $\left(\mathrm{p}_{\mathrm{i}}-\right.$ relative abundance of species, $\mathrm{n}_{\mathrm{i}}-\mathrm{a}$ number of individuals of a periphyton species found in the studied sample)

\begin{tabular}{|c|c|c|c|c|c|c|}
\hline \multirow[t]{2}{*}{ Genus / species } & \multicolumn{2}{|c|}{$\begin{array}{c}\text { 1st } \\
\text { location }\end{array}$} & \multicolumn{2}{|c|}{$\begin{array}{c}\text { 2nd } \\
\text { location }\end{array}$} & \multicolumn{2}{|c|}{$\begin{array}{c}\text { 3rd } \\
\text { location }\end{array}$} \\
\hline & $\mathrm{n}_{\mathrm{i}}$ & $p_{i}$ & $\mathrm{n}_{\mathrm{i}}$ & $p_{i}$ & $\mathrm{n}_{\mathrm{i}}$ & $p_{i}$ \\
\hline \multicolumn{7}{|l|}{ Chlorophyta } \\
\hline Cosmarium sp. & 10 & 1.22 & - & - & - & - \\
\hline $\begin{array}{c}\text { Pediastrum } \\
\text { boryanum }\end{array}$ & 5 & 0.61 & - & - & 2 & 0.05 \\
\hline $\begin{array}{c}\text { Scenedesmus } \\
\text { communis }\end{array}$ & 50 & 6.08 & 14 & 0.71 & 142 & 3.87 \\
\hline \multicolumn{7}{|l|}{ Bacillariophyta } \\
\hline Amphora ovale & 71 & 8.64 & 108 & 5.51 & 1396 & 38.06 \\
\hline Cocconeis sp. & 92 & 11.19 & 15 & 0.77 & 174 & 4.74 \\
\hline $\begin{array}{l}\text { Craticula } \\
\text { cuspidata }\end{array}$ & 100 & 12.17 & 264 & 13.48 & 148 & 4.03 \\
\hline Cymbella aspera & 6 & 0.73 & - & - & 11 & 0.3 \\
\hline $\begin{array}{c}\text { Navicula } \\
\text { lanceolata }\end{array}$ & 395 & 48.05 & 1040 & 53.09 & 1224 & 33.4 \\
\hline $\begin{array}{c}\text { Pinnularia } \\
\text { viridis }\end{array}$ & 16 & 1.95 & 14 & 0.71 & - & - \\
\hline $\begin{array}{c}\text { Pinnularia } \\
\text { acrosphaeria }\end{array}$ & 11 & 1.34 & 44 & 2.25 & 30 & 0.82 \\
\hline $\begin{array}{c}\text { Cymatopleura } \\
\text { solea }\end{array}$ & - & - & - & - & 1 & 0.03 \\
\hline $\begin{array}{c}\text { Rhoicosphenia } \\
\text { abbreviata }\end{array}$ & 45 & 5.47 & 226 & 11.54 & 39 & 1.06 \\
\hline Synedra sp. & 13 & 1.58 & 128 & 6.53 & 196 & 5.34 \\
\hline Flagillaria sp. & - & - & 3 & 0.15 & 8 & 0.22 \\
\hline Gomphonema sp. & - & - & 4 & 0,2 & - & - \\
\hline Melosira varians & - & - & - & - & 11 & 0.3 \\
\hline Lauderia sp. & - & - & - & - & 167 & 4.55 \\
\hline \multicolumn{7}{|l|}{ Ciliophora } \\
\hline Paramecium sp. & 6 & 0.73 & 9 & 0.46 & - & - \\
\hline \multicolumn{7}{|l|}{ Rhizopoda } \\
\hline Amoeba sp. & 1 & 0.12 & 7 & 0.36 & 8 & 0.22 \\
\hline Arcella sp. & - & - & 2 & 0.1 & - & - \\
\hline \multicolumn{7}{|l|}{ Euglenophyta } \\
\hline Euglena acus & - & - & 1 & 0.05 & - & - \\
\hline Euglena sp. & - & - & 78 & 3.98 & 108 & 2.94 \\
\hline \multicolumn{7}{|l|}{ Rotifera } \\
\hline Rotifera & 1 & 0.12 & 2 & 0.1 & 3 & 0.08 \\
\hline $\begin{array}{l}\text { Total number } \\
\text { of organisms }\end{array}$ & 822 & 100 & 1959 & 100 & 3668 & 100 \\
\hline $\begin{array}{c}\mathrm{H} \\
\text { (Shannon index) }\end{array}$ & \multicolumn{2}{|c|}{1.77} & \multicolumn{2}{|c|}{1.60} & \multicolumn{2}{|c|}{1.73} \\
\hline $\begin{array}{c}\text { S } \\
\text { (species richness) }\end{array}$ & \multicolumn{2}{|c|}{15} & \multicolumn{2}{|c|}{17} & \multicolumn{2}{|c|}{17} \\
\hline
\end{tabular}




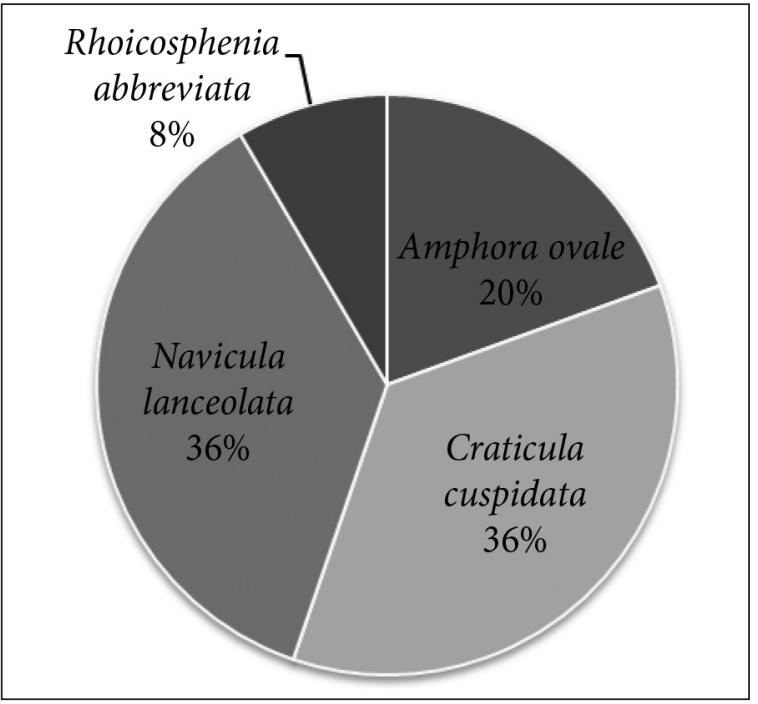

Fig. 2. Dominant species of periphyton in the Kaunas Lagoon

month, in July, instead of amoebas Euglena sp. dominated. Also, the number of green algae and Rhoicosphenia abbreviata diatoms increased. Next month, in August, diatoms Cocconeis sp., Pinnularia sp. and green algae Scenedesmus communis appeared, that were also found in periphyton in September (Fig. 4).

In the Kaunas Lagoon water $\mathrm{pH}$ was 7.8-8.4 (Table 1). Significant distribution of organisms

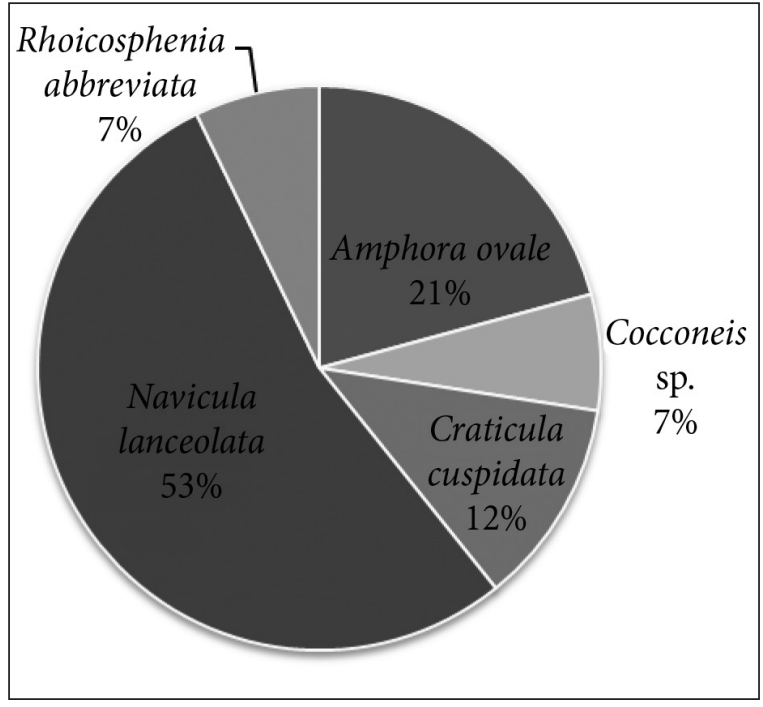

Fig. 3. Dominant species of periphyton in the $\mathrm{Ne}$ munas River

under $\mathrm{pH}$ was not observed. Water temperature ranged from $16{ }^{\circ} \mathrm{C}$ to $24^{\circ} \mathrm{C}$ (Table 1). The number of organisms and species increased when temperature reached $19^{\circ} \mathrm{C}$.

In June the Nemunas River was dominated by Paramecium sp. and Amoeba sp., diatoms Navicula lanceolata, Craticula cuspidata, Amphora ovale, Rhoicosphenia abbreviata, Cocconeis sp. No heterotrophic protozoans were

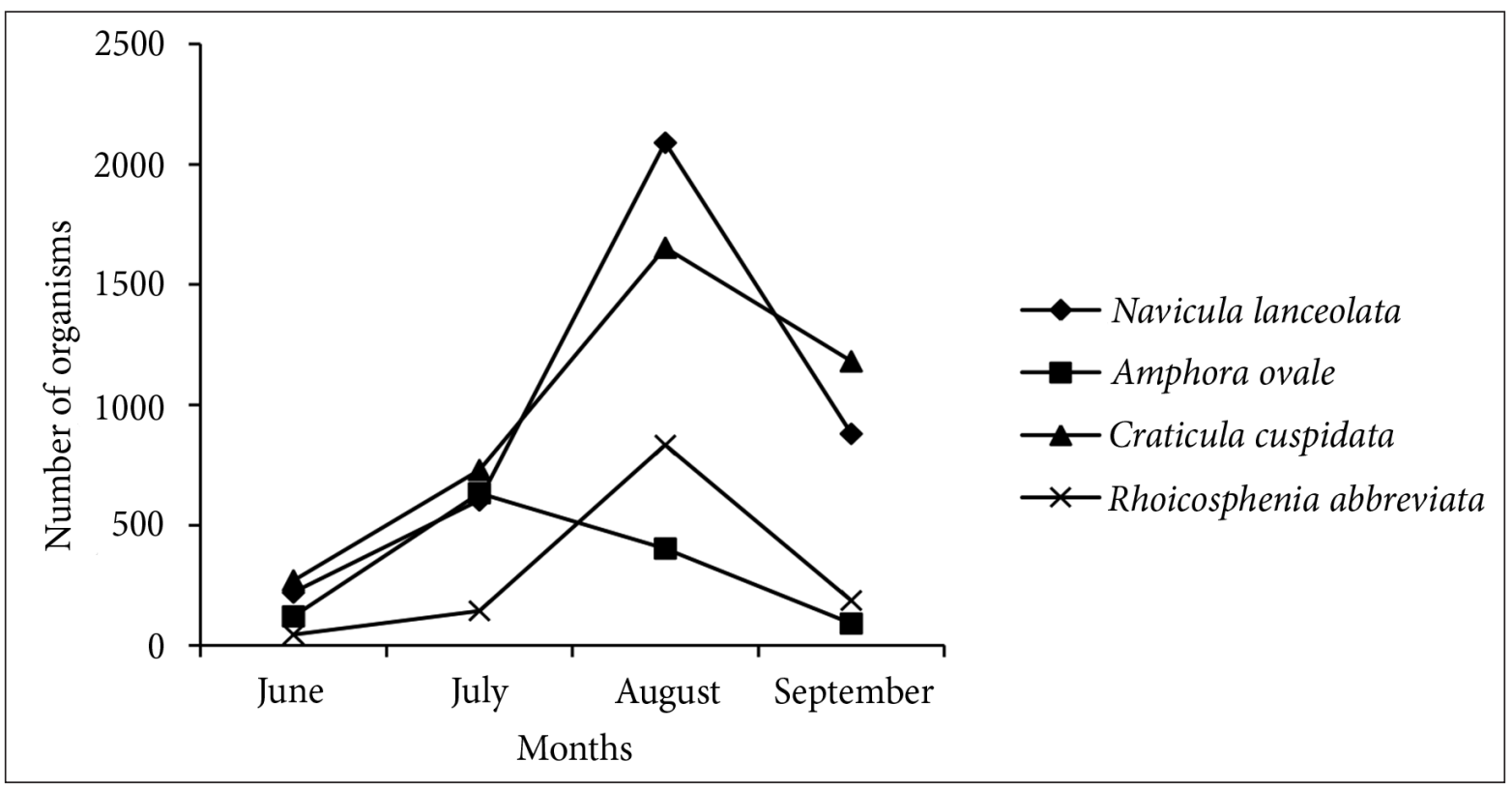

Fig. 4. Seasonal change of the dominant periphyton species in the Kaunas Lagoon 


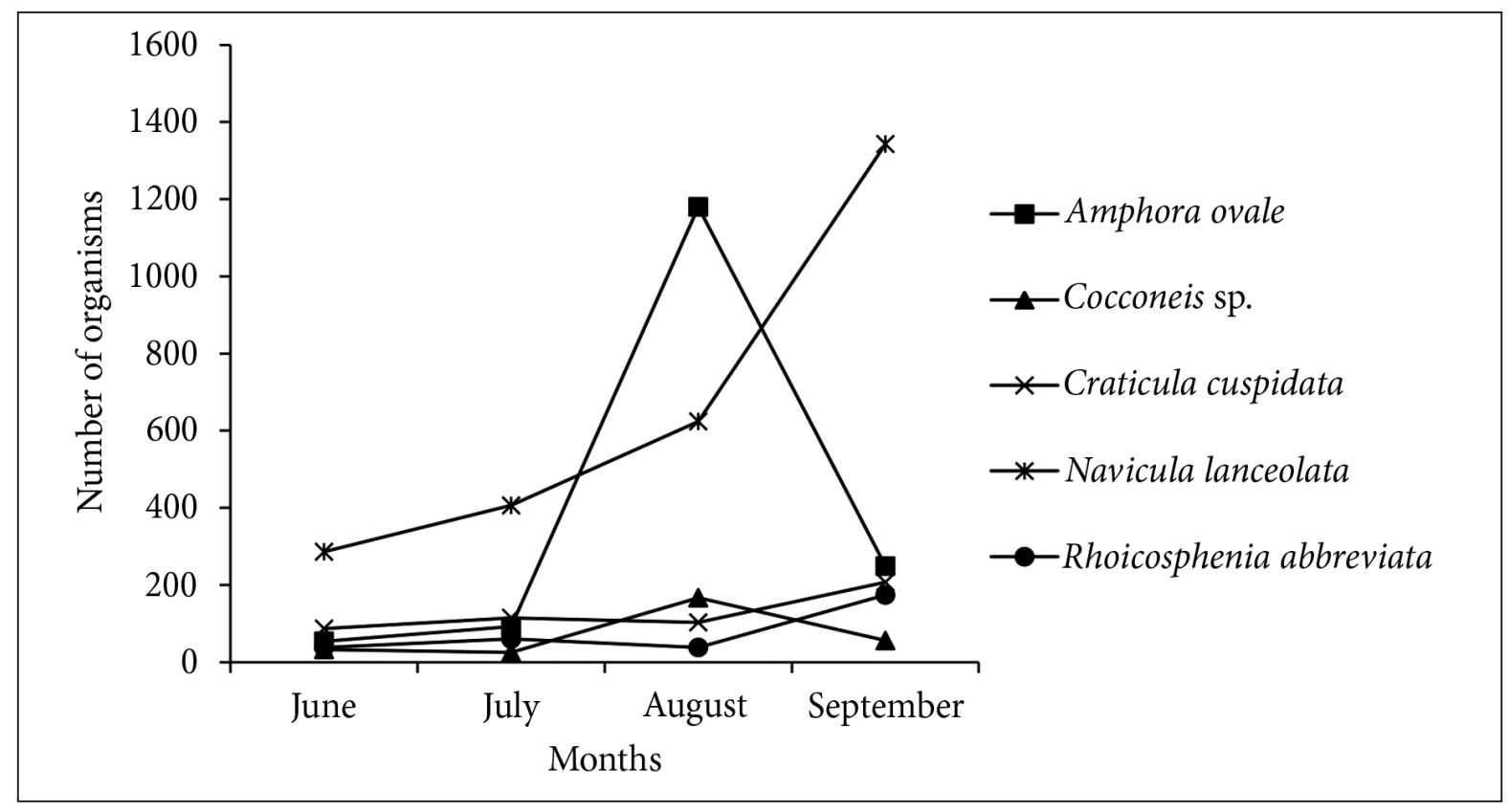

Fig. 5. Seasonal change of the dominant species in periphyton in the Nemunas River

found in July, like in the Kaunas Lagoon. The composition of the dominated species of algae was similar to that in June, also, Scenedesmus communis and Synedra sp. appeared. The communities of dominant algae remained similar in August and September. In addition, Euglena sp. was found (Fig. 5).

In the Nemunas River water $\mathrm{pH}$ was 7.4-7.8. The preliminary data suggest that organisms were most abundant when $\mathrm{pH}$ was 7.5. Water temperature ranged from $16{ }^{\circ} \mathrm{C}$ to $21{ }^{\circ} \mathrm{C}$. Organisms were most abundant when temperature was $19^{\circ} \mathrm{C}$.

Summarizing the distribution of periphyton in different months, we see that abundance of dominant periphyton species in the Kaunas Lagoon is gradually rising, when water temperature rises, and reaches the peak in late summer, when water temperature is $19{ }^{\circ} \mathrm{C}$. (Fig. 4; Table 1). Seasonal distribution of species in the Nemunas River was more significant than in the lagoon. (Fig. 5). The abundance of Scenedesmus sp., Synedra sp. and Cocconeis sp. started to decrease in late summer and was changed by Craticula cuspidata and Rhoicosphenia abbreviata which started to increase in September. The most significant change was observed in Navicula lanceolata diatoms, which also started to increase in late summer, but differently with higher abundance than the previous species. It could be due to rising water temperature and increasing number of algae. Many organisms were also found in September, although water temperature was only $16{ }^{\circ} \mathrm{C}$. It is because of dead organisms that were left on the substrate. It might also show the increased river pollution this month because Navicula lanceolata are more often found in polluted water. At the same time a significant reduction of Amphora ovale diatoms was observed. Fallen temperature and water contamination may be a possible reason, too.

Assessment of the seasonal distribution of periphyton shows that in both water bodies organisms were more abundantly found in late summer. During the first summer months heterotrophic protists Amoeba sp. and Paramecium sp. were found more abundantly, while in July autotrophic / mixotrophic Euglena sp. increased.

The analysed results showed that dominant algae species in lagoon and river were similar, namely Navicula lanceolata, Craticula 
cuspidata, Amphora ovale. The quantity and composition of other protists were different (Figs. 2 and 3). Euglena sp., Paramecium sp., Vorticella sp., Amoeba sp. dominated in the lagoon. Vorticella sp. was never found in the Nemunas River, only Arcella sp. was detected.

The abundance of rotifers was low in both water bodies - merely a few individuals. Based on the available data, it would not be possible to make conclusions about their distribution or abundance.

Regarding periphyton composition in both water bodies, we can make a preliminary conclusion that periphyton on stones is mainly composed of diatoms, but heterotrophic protists and micro multicellular organisms form a smaller part of periphyton.

Some of the genera / species found in periphyton have indicator features. Pollution tolerant genera Amphora sp., Cocconeis sp., Cymbella sp., Navicula sp., Pinnularia sp., Scenedesmus sp., Synedra sp. (Denys et al., 1989; Dickman et al., 1993; Kelly et al., 2005) were found in the Kaunas Lagoon and the Nemunas River. Diatoms like Amphora sp. and Navicula sp. (Round, 1993) are especially contamination tolerant.

Clean water usually has small amounts of different types of diatoms (Person, 1989). During the study diatoms were found abundantly in July and August in both water bodies. Diversity of algae in contaminated water decreases, however pollution tolerant species like Navicula sp. increases. Navicula sp. was abundantly found in July, August and September in the lagoon and in the Nemunas River in September.

Green algae such as Scenedesmus sp. can survive both in clean and polluted water. Euglena sp. is most resistant to pollution, it is commonly found in farm ponds, lagoons where sewage is treated, and other water bodies with high levels of nitrogen (Person, 1989). During this study, higher abundance of Euglena sp. individuals was observed in the lagoon in July, August and September. From the Nemunas River, Euglena sp. was found only in two locations in August and September.

\section{CONCLUSIONS}

The composition of dominant species in periphyton in the Kaunas Lagoon and the Nemunas River was similar: Navicula lanceolata, Craticula cuspidata, Amphora ovale. In total, 15 species and 14 genera of periphyton were collected and identified.

12 species and 12 genera of periphyton were identified in a stagnant water body, the Kaunas Lagoon. The number of organisms and species increased when temperature reached $19^{\circ} \mathrm{C}$ in July and August.

12 species and 11 genera were found in a flowing water body, the Nemunas River. Organisms were most abundant when temperature was $19^{\circ} \mathrm{C}$ in July, August, and similar abundance remained in September when water temperature was only $16^{\circ} \mathrm{C}$.

The dominant genera / species of periphyton found in the studied water bodies are good water contamination indicators and show a low water quality in the Kaunas Lagoon and the Nemunas River.

Received 3 April 2013

Accepted 27 June 2013

\section{References}

1. Andrejić JZ, Krizmanić J, Cvijan M. Diatom species composition of the Nišava river and its tributaries Jerma and Temska rivers (Southern Serbia). Arch Biol Sci 2012; 64(3): 1127-40.

2. Baykal Özer T, Açikgöz Erkaya İ, Udoh AU, Akbulut A, Yildiz K, Şen B. New records for the freshwater algae of Turkey (Tigris Basin). Turk J Bot 2012; 36: 747-60.

3. Denys L, Verbruggen C. A case of drowning the end of subatlantic peat growth and related palaeoenvironmental changes in the lower Scheldt Basin (Belgium) based on diatom and pollen analysis. Rev Palaeobot Palynol 1989; 59: 7-36.

4. Dickman M, Stewart K, Servant-Vildary M. Spatial heterogeneity of summer phytoplankton and water chemistry in a large volcanic 
spring-fed lake in Northern Iceland. Arct Alpine Res 1993; 25(3): 228-39.

5. Durska E. Secondary succession of scuttle fly (Diptera: Phoridae) communities in moist pine forest in Białowieża Forest. Fragm Faun 2001; 47: 81-130.

6. Hällfors G. Checklist of Baltic Sea Phytoplankton Species (including some heterotrophic protistan groups). Baltic Sea Environment Proceedings 2004; 95: 1-210.

7. Hameed HA. The colonization of periphytic diatom species on artificial substrates in the Ashar Canal, Basrah, Iraq. Limnologia 2003; 33: 54-61.

8. Kalytyte D. Summer phytoplankton in deep Lithuanian lakes. Ekologija 2007; 53(4): 52.

9. Kasperovičienè J. The summer phytoplankton structure of some lakes located in Lithuanian protected areas. Biologija 2001; 2: 80-3.

10. Kelly MG, Gennion H, Cox EJ, Goldmith B, Jamieson J, Juggins S, Mann DG, Telford RJ. Common Freshwater Diatoms of Britain and Ireland: An Interactive Key. Environment Agency, Bristol 2005.

11. Mather L, MacIntosh K, Kaczmarska I, Klein G, Martin JL. A checklist of diatoms species reported (and presumed native) from Canadian coastal waters. Can Tech Rep Fish Aquat Sci 2010; 2881:iii+78 p.

12. Mažeikaitė $S$. Lietuvos gèlo vandens telkinių planktono heterotrofiniai protistai. Botanikos instituto leidykla, 2003 (In Lithuanian).

13. O'Reilly CM. Seasonal dynamics of periphyton in a large tropical lake. Hydrobiologia 2006; 553: 293-301.

14. Patterson DJ. Free-living freshwater protozoa. Colour guide. ASM Press 2003.

15. Person JL. Environmental Science Investigations: How the World Works and Your Place in it. J. M. LeBel Enterprises, Ltd., Ronkonkoma, NY 1989.

16. Round FE. A review and methods for the use of epilithic diatoms for detecting and monitoring changes in river water quality: methods for the examination of water and associated materials. London: HMSO Publications 1993.

17. Schmid PE, Schmid-Araya JM. Trophic relationships in temporary and permanent freshwater meiofauna. In: Rundle SD, Robertson AL, Schmid-Araya JM. (eds.). Backhuys Publishers, Leiden, The Netherlands. Freshwater Meiofauna 2002; 295-319.

18. Schmid-Araya JM, Schmid PE. Trophic relationships: Integrating meiofauna into a realistic benthic food web. Freshwater Biol 2000; 44: 149-63.

19. Wetzel RG. Limnology: Lake and River Ecosystems, Third Edition. Academic Press, San Diego, CA 2001.

\section{Rasa Glasaitė, Ingrida Šatkauskienė \\ PERIFITONO SUDÉTIS IR İVAROVE் KAUNO MARIOSE IR NEMUNO UPĖJE}

\section{Santrauka}

Perifitoną sudaro ịvairūs prie substrato, esančio po vandeniu, prisitvirtinę organizmai: bakterijos, dumbliai, grybai, protistai ir mikrodaugialąsčiai. Perifitonas yra svarbus normaliai funkcionuojančių gèlavandenių ekosistemų maistiniams ir funkciniams ryšiams.

Kauno marios ir Nemunas yra vieni svarbiausiu gèlo vandens telkinių Lietuvoje, tačiau duomenų apie šių telkinių perifitoninius organizmus yra nedaug. Šiam tikslui buvo atliktas tiriamasis darbas, kuriuo siekta nustatyti perifitoninių organizmų ivvairovę Kauno mariose ir Nemuno upèje.

Perifitono mèginiai vandens telkiniuose nuo akmenų buvo surenkami reguliariai, kad būtų galima įvertinti perifitono bendrijų pokyčius tiriamuoju laikotarpiu. Iš viso surinkta ir identifikuota 14 perifitoną sudarančiu rūšių ir 14 genčių. Kauno mariose ir Nemuno upeje vyravo Navicula lanceolata, Craticula cuspidata, Amphora ovale. Vertinant perifitono pasiskirstymą sezonų metu, buvo pastebėta, kad perifitoninių organizmų pagausėja vasaros pabaigoje. Ryškesnè sezoninè perifitono bendrijos rūšių kaita nustatyta Nemuno upeje.

Raktažodžiai: perifitonas, rūšinė įvairové, gèlavandenès ekosistemos 
